\title{
New species, new taxon report and biogeography of the diatom genus Gomphoneis Cleve (Bacillariophyceae) in Patagonia, Chubut Province, Argentina
}

\author{
J. Patrick Kociolek, Noelia M. Uyua, Silvia E. Sala, Norma H. Santinelli \& \\ Adrián Cefarelli
}

To cite this article: J. Patrick Kociolek, Noelia M. Uyua, Silvia E. Sala, Norma H. Santinelli \& Adrián Cefarelli (2017): New species, new taxon report and biogeography of the diatom genus Gomphoneis Cleve (Bacillariophyceae) in Patagonia, Chubut Province, Argentina, Diatom Research

To link to this article: https://doi.org/10.1080/0269249X.2017.1393009

曲 Published online: 15 Dec 2017.

Submit your article to this journal $\pi$

Q View related articles $₫$

View Crossmark data ־ 


\title{
New species, new taxon report and biogeography of the diatom genus Gomphoneis Cleve (Bacillariophyceae) in Patagonia, Chubut Province, Argentina
}

\author{
J. PATRICK KOCIOLEK ${ }^{1 *}$, NOELIA M. UYUA ${ }^{2}$, SILVIA E. SALA ${ }^{3}$, NORMA H. SANTINELLI ${ }^{4}$ \& \\ ADRIÁN CEFARELLI ${ }^{3}$ \\ ${ }^{1}$ Museum of Natural History and Department of Ecology and Evolutionary Biology, University of Colorado, Boulder, CO, USA \\ ${ }^{2}$ CONICET-SCTeIP, Laboratorio de Hidrobiología, Facultad de Ciencias Naturales, Universidad Nacional de la Patagonia San Juan \\ Bosco, Trelew, Argentina \\ ${ }^{3}$ División Ficología, Facultad de Ciencias Naturales y Museo, Universidad Nacional de La Plata, La Plata, Argentina \\ ${ }^{4}$ Laboratorio de Hidrobiología, Facultad de Ciencias Naturales, Universidad Nacional de la Patagonia San Juan Bosco, Trelew, \\ Argentina
}

\begin{abstract}
The presence of three Gomphoneis species from Chubut Province in Argentina is documented with light and scanning electron microscopy. Two of the taxa, G. patagoniana and G. eriense var. variabilis, are part of the Herculeana subgroup of Gomphoneis. Gomphoneis patagoniana is a newly discovered species and G. eriense var. variabilis is reported from Argentina for the first time. These two species have evident axial plates, differentiated apical pore fields (APFs), a stigmal opening that is round externally and slit-like internally, and areolae that are mostly tri-radiate in shape. The third species, G. frenguellii, is also newly discovered and described. Presence of four isolated stigmoids, undifferentiated APFs and lack of an axial plate indicates G. frenguellii is a member of the Elegans subgroup of the genus. Presence of these newly described species, and the previously unreported taxon, may also be associated with the invasive species Didymosphenia geminata. Given there is no long history of reports of Gomphoneis in the country and, in the case of G. eriense var. variabilis, its previously known distribution, it is possible that the origin of this Gomphoneis taxon is from western North America.
\end{abstract}

Keywords: Gomphoneis, Argentina, Didymosphenia geminata, new species, new distribution record, Patagonia, Chubut

\section{Introduction}

The diatom genus Gomphoneis Cleve (1894) was initially established with three species, G. elegans (Grunow) Cleve, G. herculeana (Ehrenberg) Cleve and G. mammilla (Ehrenberg) Cleve, and has grown to currently comprise over 75 species worldwide (Fourtanier \& Kociolek 2011, Kociolek et al. 2013, You et al. 2013). Kociolek \& Stoermer $(1989,1993)$ suggested there were two subgroups within the genus. The first, including the generitype G. elegans, has either multiple stigmoids or lacks isolated pores in the central area. In addition, the 'Elegans' subgroup has undifferentiated apical pore fields (APFs) and, if longitudinal lines are present, they are formed by laminae of silica covering the margins and mantle area of the valve. While North America appears to be the area of origin of this group (Kociolek \& Stoermer 1989), many species have been described from Lake Baikal (Kociolek et al. 2013), NW China (You et al. 2013) and Europe (as Gomphonema Ehrenberg species, Levkov \& Williams 2011), and some species, such as Gomphoneis olivaceum (Hornemann) P. Dawson ex Ross \& Sims and G. quadripunctata (Østrup) P. Dawson ex Ross \& Sims, are widely distributed (Kociolek
\& Stoermer 1989, 1993). The second subgroup within the genus recognized by Kociolek \& Stoermer $(1989,1993)$, termed the 'Herculeana' subgroup, typically has a single stigma, differentiated APFs, and longitudinal lines in valve view formed by a lamina of silica underneath the valve face (termed a marginal lamina, Kociolek \& Stoermer 1988a). This subgroup may have originated in Europe, but most species are known from Western North America (Kociolek \& Stoermer 1989), with subsequent dispersal to other regions of the world.

Recent data have shed light on the phylogenetic relationships of Gomphoneis. While Kociolek \& Stoermer (1989) suggested the genus was monophyletic, further analysis (Kociolek \& Stoermer 1993) placed the Herculeana subgroup closer to Gomphonema than to congeners of the Elegans subgroup of Gomphoneis, a placement supported by molecular data (Nakov et al. 2014). Kociolek et al. (2015) showed that the Elegans subgroup may be sister to the newly described genus Gomphosinica Kociolek et al. (2015), a genus only found in China and North America.

*Corresponding author. Email: patrick.kociolek@colorado.edu Associate Editor: Mark Edlund 
Gomphoneis has not previously been widely reported in South America. Rivera and colleagues (Rivera \& Arcos 1975, Rivera et al. 1973, Rivera 1974, Rivera \& Valdebenito 1979) reported G. herculeana (Ehrenberg) Cleve, G. herculeana var. robusta (Grunow) Cleve and G. herculeana var. septiceps M. Schmidt from several rivers in Chile and Rumrich et al. (2000) and Basualto et al. (2016) reported Gomphoneis minuta (Stone) Kociolek \& Stoermer from Chile. According to Voilloud (2003), G. herculeana and G. minuta (Stone) Kociolek \& Stoermer, both from the Herculeana subgroup, were reported from Argentina. These two species are widely distributed in Patagonia and G. herculeana was also mentioned from Córdoba in the central region of the country (Luque \& Martinez de Frabricius 2003, Gari \& Corigliano 2004). Aside from the cosmopolitan species G. olivaceum (Voilloud 2003), no other species from the Elegans subgroup have previously been reported from Argentina. From a historical perspective, no species of Gomphoneis have been reported before 1980 among the diatoms of Patagonia (e.g., Frenguelli 1941, 1942).

A recent (November 2015) expedition to Chubut province, Patagonia, to document the presence of the invasive diatom Didymosphenia geminata (Lyngbye) M. Schmidt resulted in collections in the western portion of the province, and along the Chubut River. The purpose of the present report is to document and describe with light (LM) and scanning electron microscopy (SEM) the Gomphoneis species present in this region of Argentina.

\section{Materials and methods}

For LM and SEM observations, organic material was removed by following the method described in CEN (2003). For all LM observations, cleaned material was air dried onto glass coverslips and permanent slides were prepared using Naphrax (Brunel Microscopes Ltd., Chippenham, UK) mounting medium. All LM observations were performed using an Olympus BX-51 light microscope (Olympus America Inc., Center Valley, PA, USA) with a $100 \times$ oil immersion objective (numerical aperture 1.40). Light micrographs were taken using an Olympus DP71 digital camera.

For SEM observations, cleaned material was air dried onto glass coverslips, mounted onto aluminium stubs and sputter coated with ca. $1.5 \mathrm{~nm}$ gold, using a Jeol FINE COAT ION SPUTTER JFC-1100. Scanning electron microscope observations were made using a Jeol JSM$6360 \mathrm{LV}$ at the Servicio de Microscopía Electrónica del Museo de La Plata and a Carl Zeiss NTS SUPRA 40 SEM at the Centro de Microscopías Avanzadas (CMA) de la Universidad de Buenos Aires.

Slides and material used in this study are listed in Table 1 and deposited at the Nacional Museum of Natural History, La Plata, Argentina (LPC) and at JPK Diatom Collection at the University of Colorado, Boulder, USA
(COLO). We also consulted the type material of Gomphoneis herculeana var. abundans Kociolek \& Stoermer (1988a) to make measurements of the striae at the centre of the valve, and to confirm the stria densities reported for the poles. A total of 25 valves were measured from slide 021084 in the JPK Collection at COLO. The co-occurrence of the three taxa included here, along with $D$. geminata, based on visual inspection of the samples, is also presented in Table 1.

\section{Results}

Gomphoneis frenguellii Kociolek \& Sala, sp. nov.

Figs 1-19; Fig. 3 is of the holotype

Description: Valves lanceolate-clavate, with headpole protracted and broadly rounded, footpole protracted, rounded. Length $13-24 \mu \mathrm{m}$, breadth $4.0-5.5 \mu \mathrm{m}$. Axial area narrow, straight, expanded to form a wide, nearly-rectangular central area with 1-2 very short striae on either side. Four stigmoids, one positioned at the end of each of the four elongate striae bordering the central area. Raphe straight, filiform. Striae internally costate, radiate to parallel toward the headpole, radiate to the footpole, 9-13/10 $\mu \mathrm{m}$. Pseudosepta and septa present, indistinct. APF not distinguished.

Holotype: LPC 13481

Isotype: Accession Number 12289, JPK Collection (COLO).

Type Locality: LPC 13481 Argentina, Chubut Province,

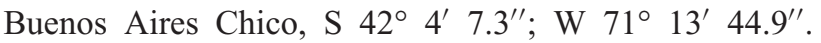
Submerged moss.

Etymology: The species is named for Joaquín Frenguelli, who was the leader in describing the diversity of diatoms in Argentina.

Comments: In the SEM, the valve exterior has a straight raphe (Figs 9-14) with distinctly dilated proximal raphe ends (Figs 12,13). In the central area four stigmoids are evident (Figs 12,13). The stigmoids are round in outline and without occlusions. Striae are doubly-punctate, formed by round, unoccluded areolae and continue without interruption from the valve face to the mantle (Figs 9-14). At the headpole, the distal raphe end is only slightly deflected and extends for a short distance onto the mantle (Fig. 10). At the footpole, porelli of the APF are of the same size and shape as the areolae, and appear continuous with them (Fig. 11). The distal raphe end is slightly bent on the valve face and then extends onto the mantle, bisecting the APF (Fig. 11). The cingulum is of the open type.

Internally, the biseriate nature of the striae is evident. The small central nodule is bordered by the four stigmoids, as well as the proximal raphe ends. The stigmoids are rounded in appearance and have teeth-like projections (Figs 15, 18, 19). The proximal raphe ends are tightly curved in the same direction, barely extending onto the central nodule (Figs 15, 18, 19). 
Table 1. List of samples used in the present study from Chubut Province, Argentina. All samples were collected by J.P. Kociolek. LPC numbers refer to designations at the Museum of Natural History, La Plata, Argentina. Taxon abbreviations include $\mathrm{D}=$ Didymosphenia geminata, $\mathrm{P}=$ Gomphoneis patagoniana, $\mathrm{F}=$ Gomphoneis frenguellii, $\mathrm{E}=$ Gomphoneis eriense var. variabilis.

\begin{tabular}{|c|c|c|c|c|c|}
\hline Collection number & Site & Locality coordinates & Sample information & Date & Taxa \\
\hline LPC 13450 & Epuyén River & $\mathrm{S} 42^{\circ} 12^{\prime} 29.6^{\prime \prime} ; \mathrm{W} 71^{\circ} 23^{\prime} 21.1^{\prime \prime}$ & Composite rock scrape. & $19-\mathrm{XI}-2015$ & $\mathrm{P}, \mathrm{F}$ \\
\hline LPC 13451 & Epuyén River & $\mathrm{S} 42^{\circ} 12^{\prime} 29.6^{\prime \prime} ; \mathrm{W} 71^{\circ} 23^{\prime} 21.1^{\prime \prime}$ & Quiet water, benthos. & $19-\mathrm{XI}-2015$ & $\mathrm{P}$ \\
\hline LPC 13452 & Epuyén River & $\mathrm{S} 42^{\circ} 12^{\prime} 29.6^{\prime \prime} ; \mathrm{W} 71^{\circ} 23^{\prime} 21.1^{\prime \prime}$. & Composite rock scrape. & $19-\mathrm{XI}-2015$ & $\mathrm{P}$ \\
\hline LPC 13453 & $\begin{array}{l}\text { Trail to waterfall Corbata } \\
\text { Blanca }\end{array}$ & $\mathrm{S} 42^{\circ} 12^{\prime} 30.3^{\prime \prime} ; \mathrm{W} 71^{\circ} 23^{\prime} 21.7^{\prime \prime}$ & $\begin{array}{l}\text { Overflowing water tower, } \\
\text { assorted mosses. }\end{array}$ & 19-XI-2015 & $\mathrm{F}$ \\
\hline LPC 13454 & $\begin{array}{l}\text { Trail to waterfall Corbata } \\
\text { Blanca }\end{array}$ & $\mathrm{S} 42^{\circ} 12^{\prime} 30.3^{\prime \prime} ; \mathrm{W} 71^{\circ} 23^{\prime} 21.7^{\prime \prime}$ & $\begin{array}{l}\text { Composite mosses from } \\
\text { stream. }\end{array}$ & $19-\mathrm{XI}-2015$ & $\mathrm{~F}$ \\
\hline LPC 13456 & $\begin{array}{l}\text { Trail to waterfall Corbata } \\
\text { Blanca }\end{array}$ & $\mathrm{S} 42^{\circ} 12^{\prime} 30.3^{\prime \prime} ; \mathrm{W} 71^{\circ} 23^{\prime} 21.7^{\prime \prime}$ & $\begin{array}{l}\text { Quiet water, brown sediments } \\
\text { and mosses. }\end{array}$ & 19-XI-2015 & $\mathrm{F}$ \\
\hline LPC 13457 & $\begin{array}{l}\text { Trail to waterfall Corbata } \\
\text { Blanca }\end{array}$ & $\mathrm{S} 42^{\circ} 12^{\prime} 30.3^{\prime \prime} ; \mathrm{W} 71^{\circ} 23^{\prime} 21.7^{\prime \prime}$ & $\begin{array}{l}\text { Benthic sediments; small } \\
\text { stream. }\end{array}$ & $19-X I-2015$ & $\mathrm{~F}$ \\
\hline LPC 13459 & $\begin{array}{l}\text { Entrance to Lago Puelo } \\
\text { National Park }\end{array}$ & $\mathrm{S} 42^{\circ} 3^{\prime} 14.4^{\prime \prime}$; W $71^{\circ} 29^{\prime} 43.1^{\prime \prime}$. & Benthos. & 20-XI-2015 & $\mathrm{D}, \mathrm{P}$ \\
\hline LPC 13460 & $\begin{array}{l}\text { Entrance to Lago Puelo } \\
\text { National Park }\end{array}$ & $\mathrm{S} 42^{\circ} 3^{\prime} 14.4^{\prime \prime} ; \mathrm{W} 71^{\circ} 29^{\prime} 43.1^{\prime \prime}$ & Isolated Charophyta. & 20-XI-2015 & $\mathrm{D}, \mathrm{P}$ \\
\hline LPC 13461 & $\begin{array}{l}\text { Entrance to Lago Puelo } \\
\text { National Park }\end{array}$ & $\mathrm{S} 42^{\circ} 3^{\prime} 14.4^{\prime \prime} ; \mathrm{W} 71^{\circ} 29^{\prime} 43.1^{\prime \prime}$ & $\begin{array}{l}\text { Floating brown mats in small } \\
\text { pond. }\end{array}$ & 20-XI-2015 & $\mathrm{D}, \mathrm{P}$ \\
\hline LPC 13462 & $\begin{array}{l}\text { Entrance to Lago Puelo } \\
\text { National Park }\end{array}$ & $\mathrm{S} 42^{\circ} 3^{\prime} 14.4^{\prime \prime} \mathrm{W} ; 71^{\circ} 29^{\prime} 43.1^{\prime \prime}$. & $\begin{array}{l}\text { Composite sample from lake } \\
\text { shore. }\end{array}$ & 20-XI-2015 & $\mathrm{D}, \mathrm{P}$ \\
\hline LPC 13464 & $\begin{array}{l}\text { Entrance to Lago Puelo } \\
\text { National Park }\end{array}$ & $\mathrm{S} 42^{\circ} 3^{\prime} 14.4^{\prime \prime} ; \mathrm{W} 71^{\circ} 29^{\prime} 43.1^{\prime \prime}$ & Rock scrape. & 20-XI-2015 & $\mathrm{D}, \mathrm{P}, \mathrm{F}$ \\
\hline LPC 13466 & River Azul & $\mathrm{S} 42^{\circ} 4^{\prime} 56.3^{\prime \prime} ; \mathrm{W} 71^{\circ} 36^{\prime}, 58.2^{\prime \prime}$ & Rock scrape; Didymosphenia. & 20-XI-2015 & $\mathrm{D}, \mathrm{P}, \mathrm{F}$ \\
\hline LPC 13467 & River Azul & $\mathrm{S} 42^{\circ} 4^{\prime} 56.3^{\prime \prime} ; \mathrm{W} 71^{\circ} 36^{\prime}, 58.2^{\prime \prime}$ & Composite rock scrape. & $20-\mathrm{XI}-2015$ & $\mathrm{D}, \mathrm{P}, \mathrm{F}$ \\
\hline LPC 13468 & River Azul & $\mathrm{S} 42^{\circ} 4^{\prime} 56.3^{\prime \prime} ; \mathrm{W} 71^{\circ} 36^{\prime}, 58.2^{\prime \prime}$ & Fast flow, composite. & $20-\mathrm{XI}-2015$ & $\mathrm{D}, \mathrm{P}, \mathrm{F}$ \\
\hline LPC 13469 & River Azul & $\mathrm{S} 42^{\circ} 4^{\prime} 56.3^{\prime \prime} ; \mathrm{W} 71^{\circ} 36^{\prime}, 58.2^{\prime \prime}$ & Composite at shoreline. & $20-\mathrm{XI}-2015$ & $\mathrm{D}, \mathrm{P}$ \\
\hline LPC 13470 & $\begin{array}{l}\text { River Azul, just upstream } \\
\text { from first River Azul site }\end{array}$ & $\mathrm{S} 42^{\circ} 2^{\prime} 13.5^{\prime \prime} ; \mathrm{W} 71^{\circ} 36^{\prime} 12.5^{\prime \prime}$ & Rock scrape. & $20-\mathrm{XI}-2015$ & $\mathrm{D}, \mathrm{P}, \mathrm{F}$ \\
\hline LPC 13471 & $\begin{array}{l}\text { River Azul, just upstream } \\
\text { from first River Azul site }\end{array}$ & $\mathrm{S} 42^{\circ}, 2^{\prime}, 13.5^{\prime \prime} ; \mathrm{W} 71^{\circ}, 36^{\prime}, 12.5^{\prime \prime}$ & Rock scrape. & 20-XI-2015 & $\mathrm{D}, \mathrm{P}, \mathrm{F}$ \\
\hline LPC 13472 & $\begin{array}{l}\text { River Azul, just upstream } \\
\text { from first River Azul site }\end{array}$ & $\mathrm{S} 42^{\circ} 2^{\prime} 13.5^{\prime \prime} ; \mathrm{W} 71^{\circ} 36^{\prime} 12.5^{\prime \prime}$ & $\begin{array}{l}\text { Diatom mucilage; } \\
\text { Didymosphenia. }\end{array}$ & 20-XI-2015 & $\mathrm{D}, \mathrm{P}$ \\
\hline LPC 13473 & $\begin{array}{l}\text { River Azul, just upstream } \\
\text { from first River Azul site }\end{array}$ & $\mathrm{S} 42^{\circ} 2^{\prime} 13.5^{\prime \prime} ; \mathrm{W} 71^{\circ} 36^{\prime} 12.5^{\prime \prime}$ & $\begin{array}{l}\text { Small rocks, no mucilage } \\
\text { evident }\end{array}$ & 20-XI-2015 & $\mathrm{D}, \mathrm{P}, \mathrm{F}$ \\
\hline LPC 13474 & $\begin{array}{l}\text { River Chubut, at small park } \\
1 \mathrm{~km} \text { outside the village of } \\
\text { El Maiten }\end{array}$ & $\mathrm{S} 42^{\circ} 3^{\prime} 31.2^{\prime \prime} ; \mathrm{W} 71^{\circ} 9^{\prime} 45.9^{\prime \prime}$ & Composite. & $20-\mathrm{XI}-2015$ & $\mathrm{D}, \mathrm{P}, \mathrm{E}, \mathrm{F}$ \\
\hline LPC 13475 & $\begin{array}{l}\text { River Chubut, at small park } \\
1 \mathrm{~km} \text { outside the village of } \\
\text { El Maiten }\end{array}$ & $\mathrm{S} 42^{\circ} 3^{\prime} 31.2^{\prime \prime} ; \mathrm{W} 71^{\circ} 9^{\prime} 45.9^{\prime}$ & Baster benthos. & $20-\mathrm{XI}-2015$ & $\mathrm{D}, \mathrm{P}, \mathrm{E}, \mathrm{F}$ \\
\hline
\end{tabular}


Table 1. Continued.

\begin{tabular}{|c|c|c|c|c|c|}
\hline Collection number & Site & Locality coordinates & Sample information & Date & Taxa \\
\hline LPC 13476 & $\begin{array}{l}\text { River Chubut, at small park } \\
1 \mathrm{~km} \text { outside the village of } \\
\text { El Maiten }\end{array}$ & $\mathrm{S} 42^{\circ} 3^{\prime} 31.2^{\prime \prime} ; \mathrm{W} 71^{\circ}, 9^{\prime} 45.9^{\prime \prime}$ & Composite collection. & 20-XI-2015 & $\mathrm{D}, \mathrm{P}, \mathrm{E}, \mathrm{F}$ \\
\hline LPC 13477 & $\begin{array}{l}\text { River Chubut, at small park } \\
1 \text { km outside the village of } \\
\text { El Maiten }\end{array}$ & $\mathrm{S} 42^{\circ} 3^{\prime} 31.2^{\prime \prime} ; \mathrm{W} 71^{\circ}, 9^{\prime} 45.9^{\prime \prime}$ & Composite rocks from river. & 20-XI-2015 & $\mathrm{D}, \mathrm{P}, \mathrm{F}$ \\
\hline LPC 13478 & $\begin{array}{l}\text { River Chubut, at small park } \\
1 \mathrm{~km} \text { outside the village of } \\
\text { El Maiten }\end{array}$ & $\mathrm{S} 42^{\circ} 3^{\prime} 31.2^{\prime \prime} ; \mathrm{W} 71^{\circ}, 9^{\prime} 45.9^{\prime \prime}$ & Benthos from shallow pool. & 20-XI-2015 & $\mathrm{D}, \mathrm{E}, \mathrm{F}$ \\
\hline LPC 13479 & Cañadón de los Ensueños & $\mathrm{S} 42^{\circ} 4^{\prime} 7.3^{\prime \prime} ; \mathrm{W} 71^{\circ} 13^{\prime} 44.9^{\prime \prime}$ & Submerged moss. & 20-XI-2015 & $\mathrm{F}$ \\
\hline LPC 13480 & Cañadón de los Ensueños & $\mathrm{S} 42^{\circ} 4^{\prime} 7.3^{\prime \prime} ; \mathrm{W} 71^{\circ} 13^{\prime} 44.9^{\prime \prime}$ & Rock scrape, fast flow. & 20-XI-2015 & $\mathrm{F}$ \\
\hline LPC 13481 & Cañadón de los Ensueños & $\mathrm{S} 42^{\circ} 4^{\prime} 7.3^{\prime \prime} ; \mathrm{W} 71^{\circ} 13^{\prime} 44.9^{\prime \prime}$ & Submerged moss. & 20-XI-2015 & $\mathrm{P}, \mathrm{F}$ \\
\hline LPC 13482 & Cañadón de los Ensueños & $\mathrm{S} 42^{\circ} 4^{\prime} 7.3^{\prime \prime} ; \mathrm{W} 71^{\circ} 13^{\prime} 44.9^{\prime \prime}$ & Submerged moss. & 20-XI-2015 & $\mathrm{F}$ \\
\hline LPC 13483 & Cañadón de los Ensueños & $\mathrm{S} 42^{\circ} 4^{\prime} 7.3^{\prime \prime} ; \mathrm{W} 71^{\circ} 13^{\prime} 44.9^{\prime \prime}$ & Rock scrape, slow flow. & 20-XI-2015 & $\mathrm{F}$ \\
\hline LPC 13484 & $\begin{array}{l}\text { Small stream on Provincial } \\
\text { Road \#4 }\end{array}$ & $\mathrm{S} 42^{\circ} 12^{\prime} 25.5^{\prime \prime} ; \mathrm{W} 71^{\circ} 6^{\prime} 22.4^{\prime \prime}$ & Filaments with epiphytes. & 21-XI-2015 & $\mathrm{P}, \mathrm{E}$ \\
\hline LPC 13485 & $\begin{array}{l}\text { Small stream on Provincial } \\
\text { Road \#4 }\end{array}$ & $\mathrm{S} 42^{\circ}, 12^{\prime} 25.5^{\prime \prime} ; \mathrm{W} 71^{\circ} 6^{\prime} 22.4^{\prime \prime}$ & Epiphytes on aquatic plants. & 21-XI-2015 & $\mathrm{P}, \mathrm{E}$ \\
\hline LPC 13488 & $\begin{array}{l}\text { River Chico Canyon, small } \\
\text { leading to waterfall }\end{array}$ & $\mathrm{S} 42^{\circ} 3^{\prime} 29.45^{\prime \prime} ; \mathrm{W} 70^{\circ} 28^{\prime} 31.38^{\prime \prime}$ & Composite sample. & 21-XI-2015 & $\mathrm{P}, \mathrm{F}$ \\
\hline LPC 13489 & $\begin{array}{l}\text { River Chico Canyon, spray } \\
\text { zone of waterfall }\end{array}$ & $\mathrm{S} 42^{\circ} 3^{\prime} 29.45^{\prime \prime} ; \mathrm{W} 70^{\circ} 28^{\prime} 31.38^{\prime \prime}$ & Composite sample. & 21-XI-2015 & $\mathrm{P}, \mathrm{F}$ \\
\hline LPC 13490 & $\begin{array}{l}\text { River Chico Canyon, spray } \\
\text { zone of waterfall }\end{array}$ & $\mathrm{S} 42^{\circ} 3^{\prime} 29.45^{\prime \prime} ; \mathrm{W} 70^{\circ} 28^{\prime} 31.38^{\prime \prime}$ & Composite sample. & 21-XI-2015 & $\mathrm{P}, \mathrm{F}$ \\
\hline LPC 13491 & $\begin{array}{l}\text { River Chico Canyon, small } \\
\text { wetland away from } \\
\text { waterfall }\end{array}$ & $\mathrm{S} 42^{\circ} 3^{\prime} 31.53^{\prime \prime} ; \mathrm{W} 70^{\circ} 28^{\prime} 27.92^{\prime \prime}$ & Composite sample. & 21-XI-2015 & $\mathrm{P}, \mathrm{F}$ \\
\hline LPC 13492 & $\begin{array}{l}\text { River Chico Canyon, small } \\
\text { wetland away from } \\
\text { waterfall }\end{array}$ & $\mathrm{S} 42^{\circ} 3^{\prime} 31.53^{\prime \prime} ; \mathrm{W} 70^{\circ} 28^{\prime} 27.92^{\prime \prime}$ & Composite sample. & 21-XI-2015 & $\mathrm{D}, \mathrm{P}, \mathrm{F}$ \\
\hline
\end{tabular}

km outside the village of

$\mathrm{km}$ outside the village of

El Maite

er Chico Canyon, small

leading to waterfa

on, spray zone of waterfal

ver Chico Canyon, sm waterfall

wetland away from 

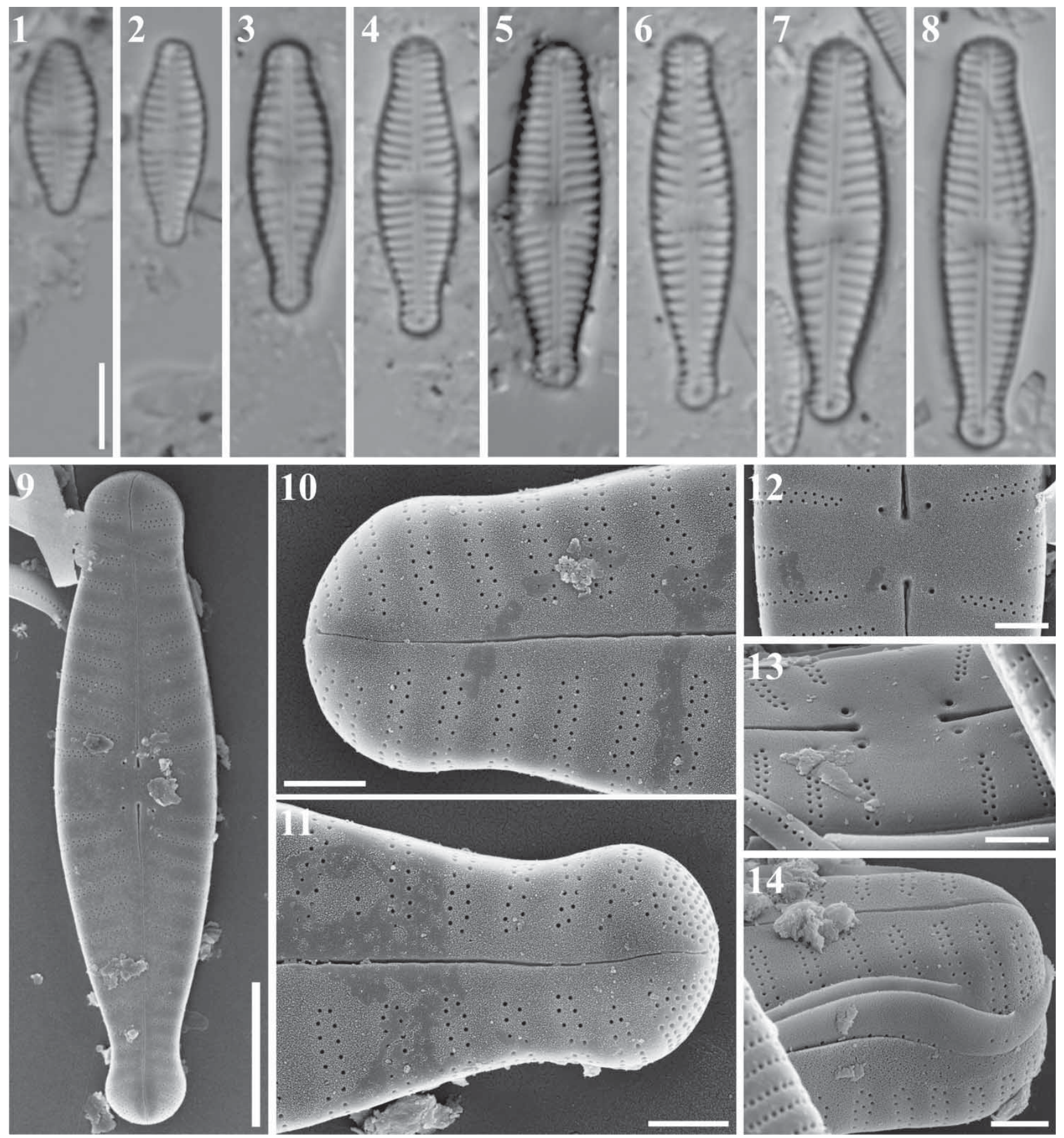

Figs. 1-14. Gomphoneis frenguellii, sp. nov. Light microscopy. Size diminution series. Fig. 3 is of the holotype. All LM images are from sample LPC 13481. Scale bar $=10 \mu \mathrm{m}$. Gomphoneis frenguellii. SEM, external views. Fig. 9. Whole valve view showing the elliptical-lanceolate valve shape with rounded poles, straight raphe with dilated proximal ends and four stigmoids. Fig. 10. Headpole, with protracted apex, doubly-punctate striae composed of round areolae. The distal raphe end is straight and extends a short distance onto the mantle. Fig. 11. Footpole, showing APF positioned almost entirely on the mantle, bisected by the distal raphe end. Porelli are similar in size and structure to the areolae. Figs 12, 13. Central area with dilated proximal raphe ends, stigmoid openings with and without occlusions and doubly-punctate striae terminating near the central area in a single areola. Fig. 14. Headpole, showing that striae extend continuously from valve face to mantle. All SEM images are from sample LPC 13481. Scale bars $=5 \mu \mathrm{m}$ (Fig. 9), $1 \mu \mathrm{m}$ (Figs 10-14).

Internally, the stria-like nature of the APF is evident (Fig. 17). At the footpole and headpole, the helictoglossae and narrow pseudosepta can be seen (Figs 16, 17).
This species forms Janus cells (McBride \& Edgar 1998, Kociolek \& Stoermer 2010), with one valve having much coarser striae than the other valve, hence the great range in stria densities for this taxon. 

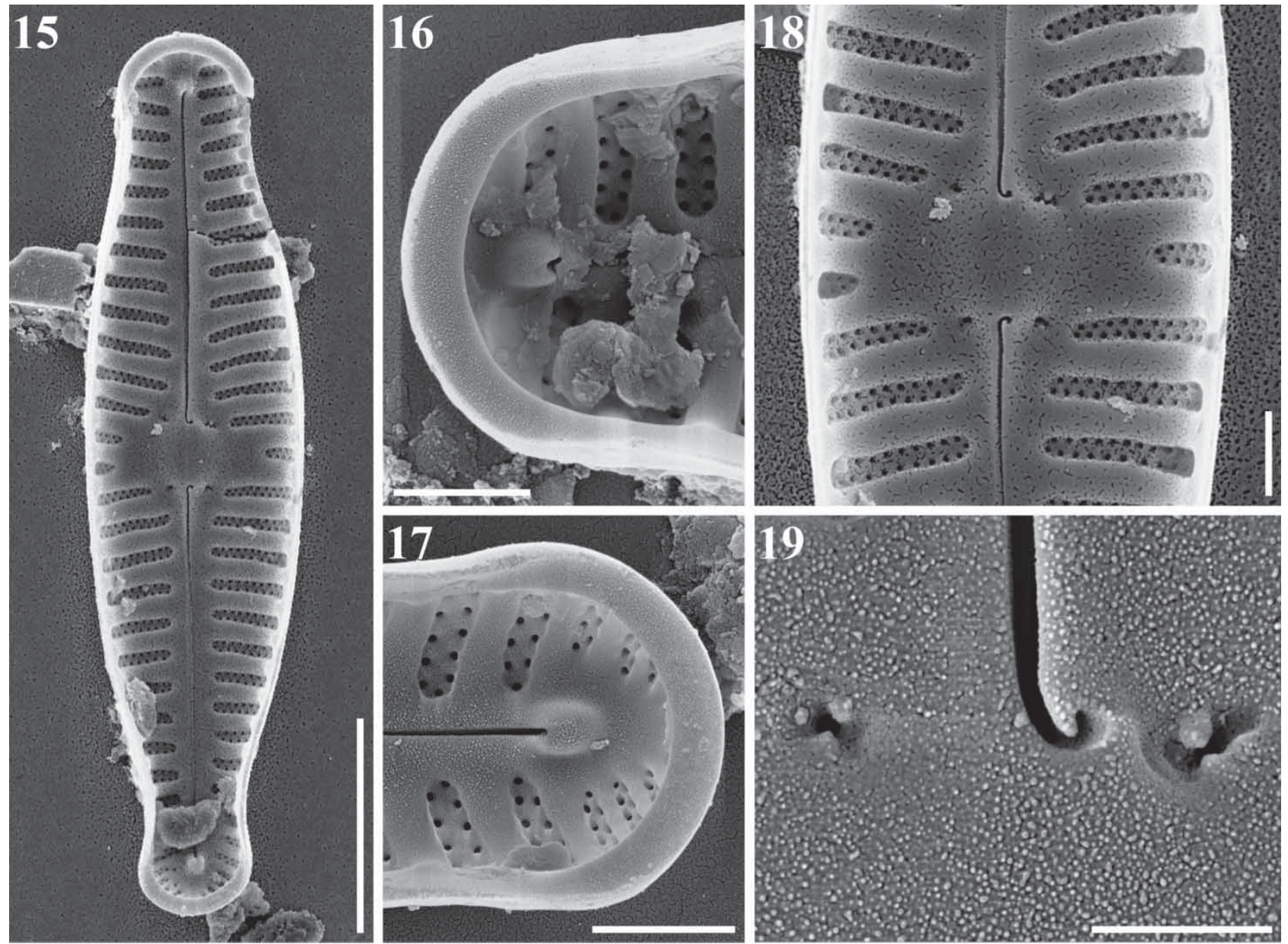

Figs. 15-19. Gomphoneis frenguellii. SEM, internal views. Fig. 15. Whole valve view with broad striae, straight raphe and rounded central nodule evident. Pseudosepta at the poles are narrow. Fig. 16. Headpole, with narrow pseudosepta and evident helictoglossa. Fig. 17. Footpole, showing the APF is composed on double rows of pores similar to the striae separated by thinner interstriae. The helictoglossa is evident. Fig. 18. Central area, with doubly-punctate striae evident. The small central nodule bears tightly recurved, short proximal raphe ends and bordered at four corners by stigmoid openings. Fig. 19. Stigmoids with small tooth-like projections near curved proximal raphe end. Scale bar $=0.5 \mu \mathrm{m}$. All SEM images are from sample LPC 13481. Scale bars $=5 \mu \mathrm{m}$ (Fig. 15), $1 \mu \mathrm{m}$ (Figs 16-18), 0.5 $\mu \mathrm{m}$ (Fig. 19).

This species resembles Gomphonema olivaceoides var. hutchinsoniana Patrick (1971), differing in the shape of the valve, and morphometric data (length: $15-18 \mu \mathrm{m}$; breadth: 5-6 $\mu \mathrm{m}$ and stria density $13-14 / 10 \mu \mathrm{m})$. Also G. olivaceoides var. hutchinsoniana has curved terminal raphe fissures; the proximal raphe ends do not reach the central area, which is delimited by two shortened striae on one side and one in the other. Though we attempted to compare our new species with the type material of Patrick's taxon, it appears to have been lost (M. Potapova, personnel communication, 3 April 2017).

Distribution in Chubut Province: Epuyén River (LPC 13450); Trail to waterfall Corbata Blanca (LPC1345313454,13456- 13457); Entrance to Lago Puelo National Park (LPC13461, 13464); River Azul (13466, 1346913478), River Chubut; Cañadón de los Ensueños (LPC 13479-13483) and River Chico Canyon (LPC 1348813490).
Gomphoneis patagoniana Kociolek \& Sala, sp. nov.

Figs 20-36; Fig. 24 is of the holotype.

Description: Valves lanceolate-clavate, distinctly tumid in the central area, with headpole somewhat protracted and broadly rounded, footpole rounded. Length $51-143 \mu \mathrm{m}$, breadth $14.0-24.5 \mu \mathrm{m}$. Axial area straight, expanded to form a small nearly circular central area bearing a single distinct stigma opening. Raphe straight, lateral, with external proximal ends dilated and distal ends deflected onto the mantle in the same direction, opposite the stigma-bearing side of the valve. Longitudinal lines are evident about $2 / 3$ of the way between the axial area and margin. Striae curved and radiate, strongly so at the footpole, comprising double rows of areolae, $11-13 / 10 \mu \mathrm{m}$ at the centre, $10-13 / 10 \mu \mathrm{m}$ at the headpole, $11-13 / 10 \mu \mathrm{m}$ at the footpole. Large and distinct pseudoseptum and septum present at both poles. Bilobed APFs differentiated from the areolae of the striae. 

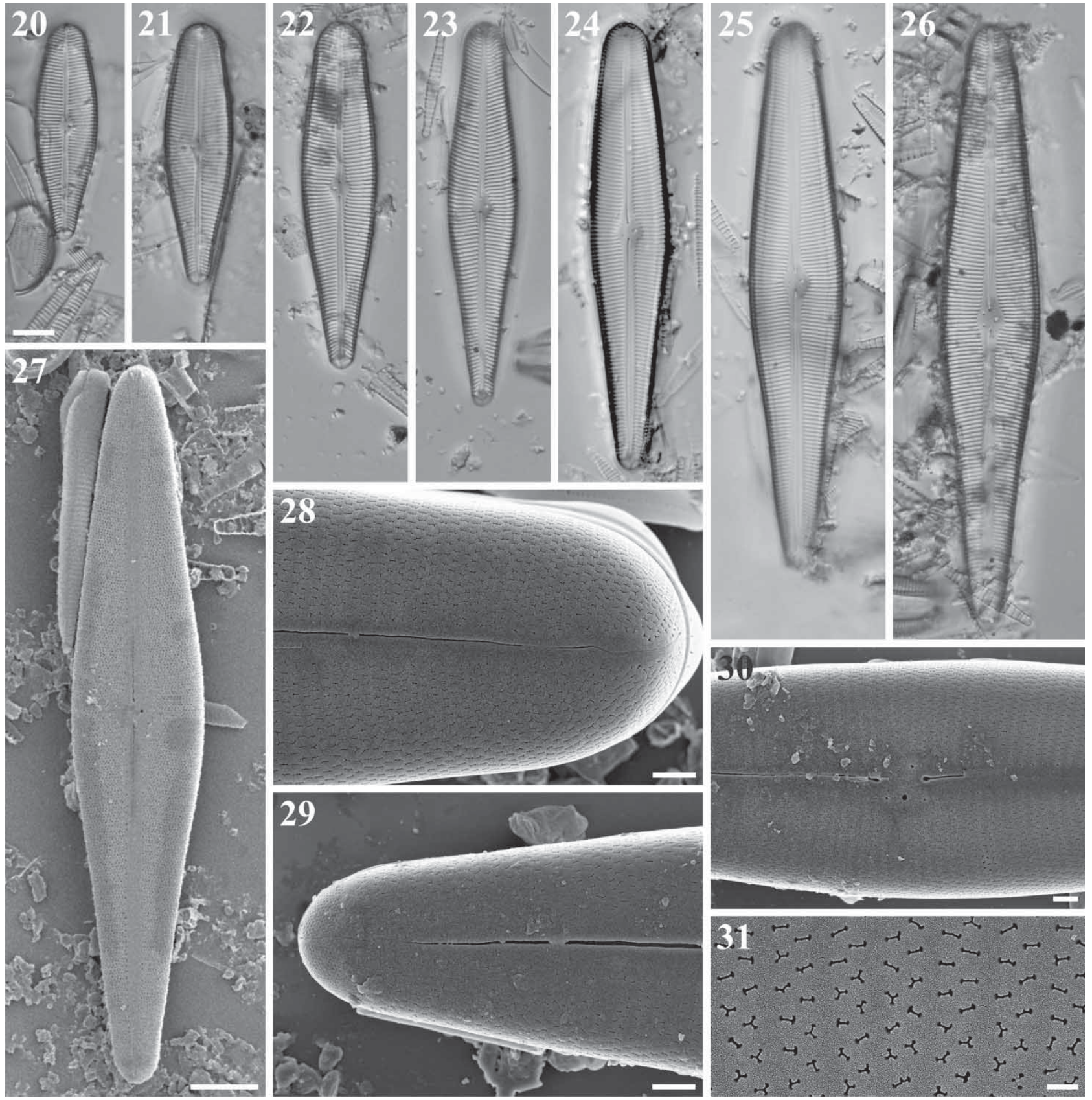

Figs. 20-31. Gomphoneis patagoniana, sp. nov. Light microscopy. Size diminution series. Fig. 24 is of the holotype. All LM images are from sample LPC 13490. Scale bar $=10 \mu \mathrm{m}$. Gomphoneis patagoniana. SEM, external views. Fig. 27. Whole valve view showing rhomboid-clavate valve outline and straight raphe. Fig. 28. Headpole, with dumbbell-shaped to tri-radiate areolae. The distal raphe end is curved and extends onto the valve mantle. Fig. 29. Footpole showing bilobed APF composed of round porelli, distinguished morphologically and separate from areolae. Fig. 30. Central area with relatively large, round stigma opening, dilated proximal raphe ends and tri-radiate areolae. Fig. 31. View of slit-like to tri-radiate areolae. All SEM images are from sample LPC 13490. Scale bars $=10 \mu \mathrm{m}$ (Fig.27), $2 \mu \mathrm{m}$ (Figs 28-30), $0.5 \mu \mathrm{m}$ (Fig. 31).

In the SEM, the valve exterior is dominated by stria areolae organized in double rows, of a variety of shapes, including straight lines with bulbous ends to tri-radiate (Figs 27-31). The raphe is relatively straight. Proximal raphe ends are dilated, and the stigma opening is round and much larger than the areolae (Fig. 30). At the footpole, the distal raphe end bisects the bilobed APF. The APF is composed of groups of small porelli, which are physically separate and morphologically different from the areolae (Fig. 29). At the footpole, the distal raphe end extends onto the valve mantle (Fig. 28). The cingulum is of the open type. 


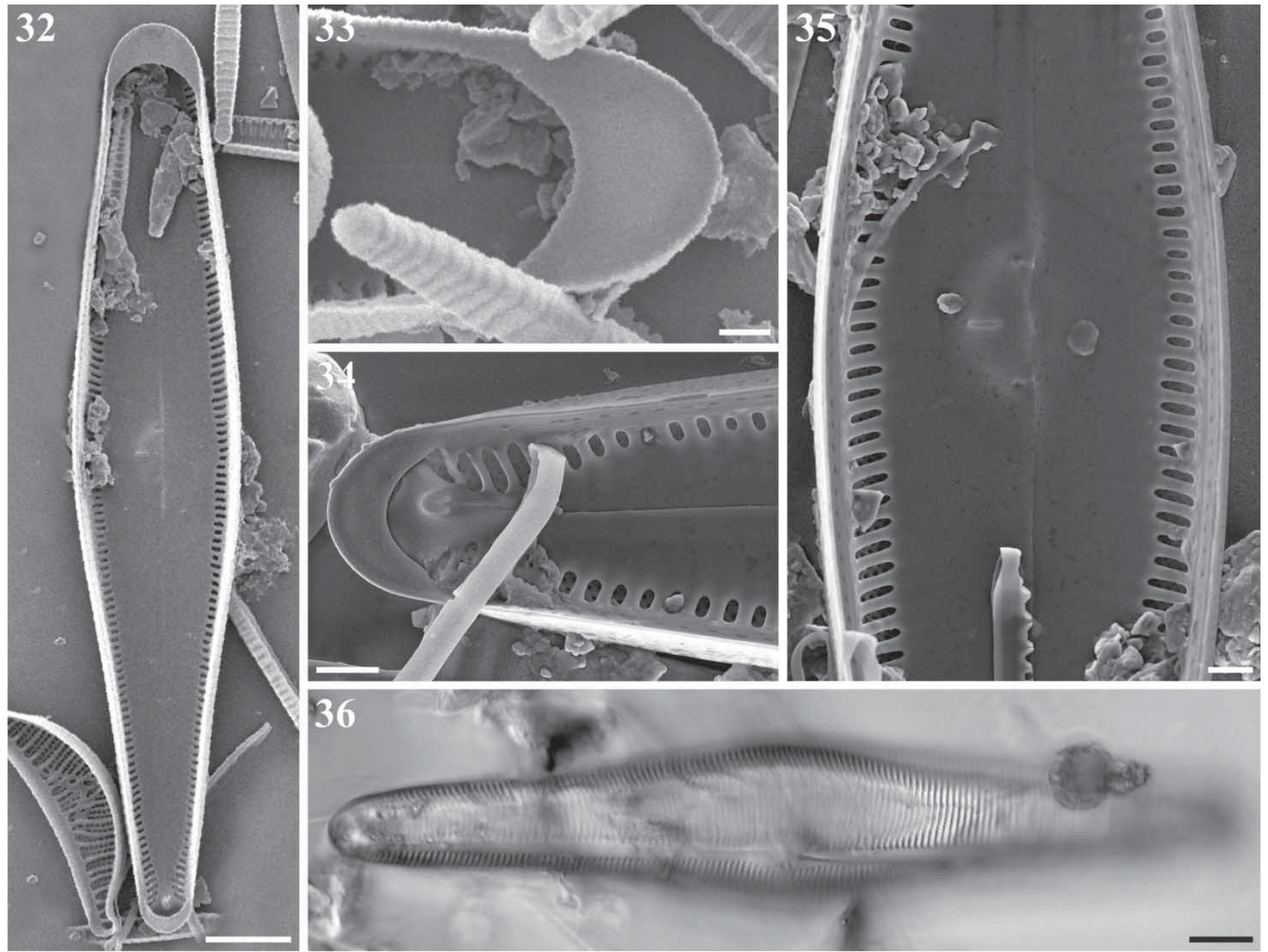

Figs. 32-36. Gomphoneis patagoniana. SEM, internal views, LM. Fig. 32. Whole valve view showing wide axial plate, with elongate, inwardly-projecting central nodule and distinct pseudosepta at the poles. Fig. 33. Headpole with distinct pseudoseptum. Helictoglossa is covered and not visible due to the presence of the pseudoseptum. Fig. 34. Footpole, with evident pseudoseptum and helictoglossa present. Fig. 35. Central part of the valve. The central nodule has recurved proximal raphe ends at either end. A distinct, thickened, slit-like stigma opening is evident. Openings of the areolae into the centre of the valve are limited, due to the presence of the axial plate and marginal lamina. Fig. 36. LM, Initial valve. All SEM images are from sample LPC 13490. Scale bars $=10 \mu \mathrm{m}($ Figs 32,36$), 2 \mu \mathrm{m}$ (Figs 33-35).

Table 2. Comparison of size and stria density for Gomphoneis species similar to G. herculeana, based on Kociolek \& Stoermer (1988a) and the current work, including a re-examination of the type material of $G$. herculeana var. abundans $(*)$.

\begin{tabular}{lcccc}
\hline Taxa & Length & Width & Striae in $10 \mu \mathrm{m}$ centre & Striae in $10 \mu \mathrm{m}$ poles \\
\hline G. patagoniana & $51-143 \mu \mathrm{m}$ & $14.0-24.5 \mu \mathrm{m}$ & $11-13$ & $\begin{array}{c}10-13 \text { at headpole } \\
11-13 \text { at footpole } \\
12-14 \text { at headpole } \\
\text { G. herculeana }\end{array}$ \\
$\begin{array}{l}\text { G. herculeana } \text { var. abundans } \\
\text { G. } \text { minuta }\end{array}$ & $76-165 \mu \mathrm{m}$ & $22-34 \mu \mathrm{m}$ & $8-12$ & $\begin{array}{c}13-16 \text { at footpole } \\
12-14 \text { at headpole } \\
13-16 \text { at footpole } \\
\text { Not reported }\end{array}$ \\
\hline
\end{tabular}

Internally, the valve is dominated by the wide axial plate (Figs 32-35). The elongate central nodule bears recurved proximal raphe ends and a large, thickened slit-like stigma opening. The internal lamina of the axial plate allows only a small area of the striae to be evident (Figs 32, 35). The footpole bears a distinct helictoglossa 
and the pseudoseptum covers the bilobed APF (Fig. 34). A large pseudoseptum is present at the headpole (Fig. 33). Septa are present on the valvocopulae.

Holotype: LPC 13490

Isotype: Accession Number 12296, JPK Collection (COLO)

Type Locality: Argentina, Chubut Province, River Chico Canyon.

Etymology: The species is named for the region in Argentina in which it is found in this study.

Comments: Auxospores (Fig. 36) of G. patagoniana are 138-143 $\mu \mathrm{m}$ long, significantly larger than those in $G$. minuta (Kociolek \& Stoermer 1988a); the cells are more lanceolate than $G$. herculeana var. abundans (the latter taxon is more club-shaped in outline), but more linear than the nominate variety. Gomphoneis patagoniana also has fewer striae per $10 \mu \mathrm{m}$ at the footpole than $G$. herculeana var. abundans. A comparison of this new species with other similar taxa is presented in Table 2.

Distribution in Chubut Province: River Epuyén (LPC 13450-13452); Trail to waterfall Corbata Blanca (LPC 13457); Entrance to Lago Puelo National Park (LPC 13459-13460, 13462, 13464); River Azul (LPC 1346813471, 13473); River Chubut (LPC 13474-13478); River Buenos Aires Chico (LPC 13479-13482); Small stream on Provincial Road \#4 (LPC 13484-13485), River Chico Canyon (LPC 13488-13492); River Chubut Fofo Cahuel (LPC 13493).

Gomphoneis eriense var. variabilis Kociolek \& Stoermer

Figs 37-48

Description: Large valves are lanceolate-clavate, broadest at centre or slightly towards the footpole, with a protracted headpole and broadly rounded footpole. Length 38-49 $\mu \mathrm{m}$, breadth $9.0-10.0 \mu \mathrm{m}$. Axial area narrow, straight, expanded to form a linear central area with a single, distinct round stigma opening. Striae comprise double rows of areolae, indistinct, radiate, $10-13$ in $10 \mu \mathrm{m}$ in the central portion of the valve and parallel to radiate at the headpole, and strongly radiate, 14-16 in $10 \mu \mathrm{m}$, at the footpole. APFs are bilobed and differentiated from the areolae near the footpole. Septa and pseudosepta present at the poles. Longitudinal lines are distinct near the axial area.

In the SEM, the valve exterior has doubly-punctate striae, composed of straight or triangular-shaped areolae (Figs 41-44). The raphe is undulate and the central area bears a round, distinct stigma (Figs 41, 44). Proximal raphe ends are slightly rounded. At the footpole, the bilobed APF is composed of round porelli and located almost exclusively on the valve mantle (Figs 43, 45). The APF is bisected by the distal raphe end, which is deflected on the valve face and extends across the mantle (Fig. 43). Porelli of the APF are physically separated and morphological distinct from the areolae. At the headpole, the distal raphe end extends onto the mantle and is sharply deflected to one side (Fig. 42).

Internally, the axial plate is narrowly lanceolate and extends between the two helictoglossae (Figs 46-48). The mound-like central nodule bears the recurved proximal raphe ends and slit-like stigma opening (Figs 46, 48). At the footpole, the helictoglossa is offset slightly from the raphe and there is a short pseudoseptum (Fig. 47). A large pseudoseptum is present at the headpole (Fig. 46). The cingulum is of the open type. Septa are present on the valvocopulae.

Comments: This is the most widely distributed species of Gomphoneis in North America, with its largest populations in the western part of the USA (Kociolek \& Stoermer 1988a).

Distribution in Chubut Province: Epuyén River (LPC 13452); Entrance to Lago Puelo National Park (LPC 13460, 13464); River Azul (LPC 13471); River Chubut (LPC 13474, 13476- 13477), Small stream on Provincial Road \#4 (LPC 13484-13485); River Chico Canyon (LPC 13488-13492); River Chubut Fofo Cahuel (LPC 13495).

This is a new taxon report for Argentina.

\section{Discussion}

Taxa of both subgroups of Gomphoneis were present in the freshwater ecosystems of Chubut Province, Patagonia. Of the Herculeana subgroup, G. eriense var. variabilis has not been reported previously from Argentina. Gomphoneis eriense var. variabilis has been known previously only from the western United States (Kociolek \& Stoermer 1988a), suggesting dispersal from this region of North America. The known distribution of $G$. eriense var. variabilis from many localities in western North America (Kociolek \& Stoermer 1988a) adds evidence to the suggestion that this taxon has dispersed from a source in that part of the USA. This might also suggest the possible population source of invasive $D$. geminata in Patagonia.

Of the Elegans subgroup, one new species, G. frenguellii, is reported. This is the first report of a quadristigmoid gomphonemoid diatom of this genus in Argentina, although there are previous reports of G. olivaceum (an astigmoid taxon) (Voilloud 2003). This Gomphoneis subgroup is well-known throughout Asia (Kociolek \& Stoermer 1988b, Tuji 2005, Kociolek et al. 2013), North America (Stoermer et al. 1999, Kociolek 2014) and Europe (Hustedt 1950, Krammer \& Lange-Bertalot 1986).

Verified records of Gomphoneis taxa in collections from South America date back to 1964 from Chile (Rivera 1974, Kociolek \& Stoermer 1988a, Santinelli et al. 1996). There are no Didymosphenia in these older samples from Chile (personal observations on Rivera's samples sent to JPK; see Kociolek \& Stoermer 1988a). However, the earliest records of Didymosphenia in Chile pre-date these 

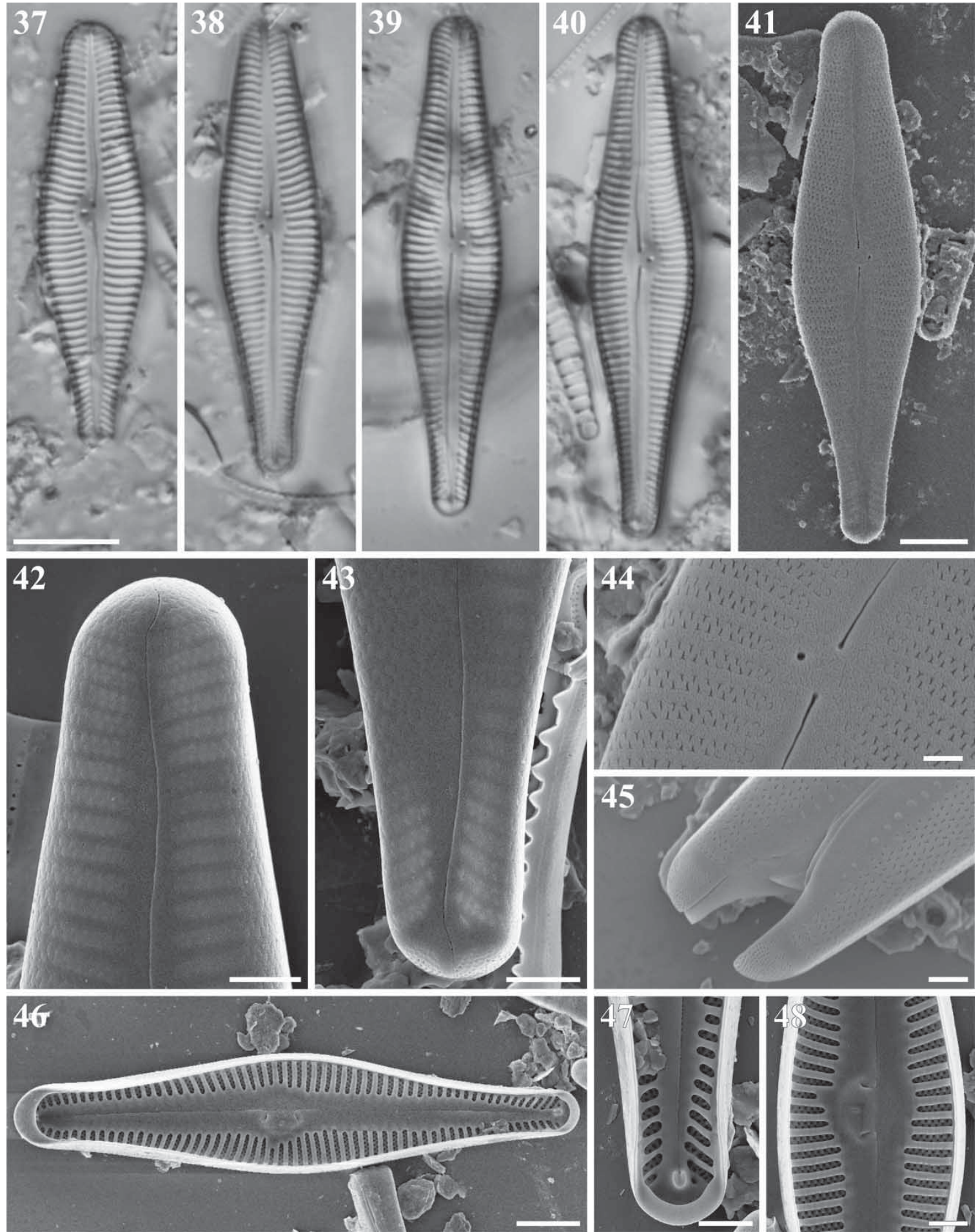

Figs. 37-48. Gomphoneis eriense var. variabilis. Light microscopy. Size diminution series. Figs 41-45. G. eriense var. variabilis. SEM, external views. Fig. 41. Whole valve view showing broadly lanceolate-clavate valve outline and undulate raphe. Fig. 42. Headpole, with tri-radiate areolae. The distal raphe end is curved and extends onto the valve mantle. Fig. 43. Footpole showing bilobed APF present on the valve mantle only and composed of round porelli, distinguished morphologically and separate from areolae. Fig. 44. Central area with relatively large, round stigma opening and distinguished from the tri-radiate areolae. Fig. 45. Footpole, girdle view, with APF physically separated from striae and positioned on the mantle. Figs 46-48. SEM, internal views. Fig. 46. Whole valve view showing wide axial plate, with elongate, inwardly-projecting central nodule and distinct pseudosepta at the poles. Helictoglossa at the headpole is covered and not visible due to pseudoseptum. Fig. 47. Footpole, with evident pseudoseptum and helictoglossa present. Fig. 48. Central part of the valve. The central nodule has recurved proximal raphe ends at either end. A distinct, slit-like stigma opening is evident. The axial plate is narrow and underlies a small portion of the striae. All images are from LPC 13489. Scale bars $=10 \mu \mathrm{m}$ (Figs $37-40)$, $5 \mu \mathrm{m}$ (Figs 41 , 46), $2 \mu \mathrm{m}$ (Figs 42, 43, 45, 47), $1 \mu \mathrm{m}$ (Figs 44, 48). 
records (Asprey et al. 1964), although they have never been subsequently verified. In Argentina, the first report of Didymosphenia is more recent (2010, Sastre et al. 2013). In our 2015 collections from Argentina, Gomphoneis taxa are nearly always associated with Didymosphenia. The relatively recent observations of Gomphoneis and Didymopsphenia in Chile (Basualto et al. 2016) and Argentina may point to them being introduced species; it is uncertain which arrived first. Gomphoneis was identified from New Zealand decades before the first report of Didymosphenia there (Wood 1961, Foged 1978, Kociolek \& Stoermer 1988a). Based on the phylogeny and biogeography of Gomphoneis (Kociolek \& Stoermer 1989), it is likely that, similar to New Zealand, members of the genus are not native to South America, and have been secondarily introduced to the continent. It may be that the Gomphoneis species treated here are 'early warning' invasive species, and documenting their presence may be helpful to understanding the spread of species with which they are associated, such as D. geminata.

\section{Acknowledgments}

We thank Mr Edgardo Uyua and Mrs Carla Kociolek for logistical support during the fieldwork in Patagonia. NMU is a Doctoral Fellow cofinanced by the National Council of Scientific and Technical Research (CONICET, Argentina) and the Chubut Provincés Science, Technology and Productive Innovation Secretariat (SCTeIP, Chubut Province, Argentina). A Fulbright Scholarship to JPK also facilitated this work.

\section{Disclosure statement}

No potential conflict of interest was reported by the authors.

\section{Funding}

This work was supported by Chubut Province's Science, Technology and Productive Innovation Secretariat (SCTeIP, Chubut Province, Argentina); National Council of Scientific and Technical Research (CONICET, Argentina); US-Polish Fulbright Commission.

\section{References}

Asprey J.F., Benson-Evans K. \& Furet J.E. 1964. A contribution to the study of South American freshwater phytoplankton. Gayana Botánica 10: 1-18.

Basualto S., Rivera P., Cruces F., Ector L. \& AscenCIO E. 2016. Didymosphenia geminata (Lyngbye) M. Schmidt y Gomphoneis minuta (Stone) Kociolek \& Stoermer (Bacillariophyta), especies presentes en ríos de la VIII Región, Chile, formadoras de proliferaciones con aspecto muy similar. Gayana Botánica 73: 457-461.

CEN. European Committee for Standardization. 2003/TC230. Water quality-Guidance standard for the routine sampling and pretreatment of benthic diatoms from rivers. prEN 13946. 14 pp.
Cleve P.T. 1894. Synopsis of the naviculoid diatoms. Part 1. Kongliga Svenska Vetenskaps - Akadamiens Handlingar 26: 1-194.

Foged N. 1978. Diatoms in Eastern Australia. Bibliotheca Phycologica 41: 1-148.

Fourtanier E. \& KocioleK J.P. 2011. Catalogue of Diatom Names, California Academy of Sciences, On-line Version. http://research.calacademy.org/research/diatoms/names/ index.asp

Frenguelli J. 1941. Algunas Diatomeas nuevas o raras del Superpatagoniense del Chubut (Patagonia). Darwiniana 5: 224-227.

Frenguelli J. 1942. Diatomeas del Neuquén (Patagonia). Revista del Museo de la Plata, Nueva Serie, Sección Botánica 5: 73-219.

Gari N. \& Corigliano M. Del C. 2004. La estructura del perifiton y de la deriva algal en arroyos serranos. Limnetica 23: 11-24.

HustedT F. 1950. Die Diatomeenflora norddeutscher Seen mit besonderer Berücksichtigung des holsteinischen Seengebiets V-VII. Seen in Mecklenburg, Lauenburg und Nordostdeutschland. Archiv für Hydrobiologie 43: 329-458.

KocIOLEK J.P. 2014. Gomphoneis pseudokunoi. In Diatoms of the United States. Retrieved February 13, 2016, from http:// westerndiatoms.colorado.edu/taxa/species/gomphoneis_ pseudokunoi

Kociolek J.P., Kulikovskiy M.S. \& Solak C.N. 2013. The diatom genus Gomphoneis Cleve (Bacillariophyceae) from Lake Baikal, Russia. Phytotaxa 154: 1-37.

Kociolek J.P. \& Stoermer E.F. 1988a. Taxonomy, ultrastructure, and distribution of Gomphoneis herculeana, G. eriense and closely related species. Proceedings of the Academy of Natural Sciences of Philadelphia 140: 24-97.

Kociolek J.P. \& Stoermer E.F. 1988b. Taxonomic and systematic position of the Gomphoneis quadripunctata species complex. Diatom Research 3: 95-108.

Kociolek J.P. \& Stoermer E.F. 1989. Phylogenetic relationships and evolutionary history of the diatom genus Gomphoneis. Phycologia 28: 438-454.

Kociolek J.P. \& StOermer E.F. 1993. Freshwater gomphonemoid diatom phylogeny: preliminary results. Hydrobiologia 269/270: 31-38.

Kociolek J.P. \& Stoermer E.F. 2010. Variation and polymorphism in diatoms: the triple helix of development, genetics and environment. A Review of the Literature. Vie et Milieu 60: 75-87.

Kociolek J.P., You Q., Wang X. \& LiU Q. 2015. Consideration of some interesting freshwater gomphonemoid diatoms from North America and China, and the description of Gomphosinica, gen. nov. Nova Hedwigia, Beihefte 144: 175-198.

Krammer K. \& LAnge-Bertalot H. 1986. Bacillariophyceae 1. Teil: Naviculaceae. In: Süsswasserflora von Mitteleuropa (Ed. by H. ETTLET AL.), Vol. 2, Issue: 1.876 pp. VEB Gustav Fisher Verlag, Jena.

LeVkov Z. \& Williams D.M. 2011. Fifteen new diatom (Bacillariophyta) species from Lake Ohrid, Macedonia. Phytotaxa 30: 1-41.

Luque M.E. \& Martinez de Frabricius A.L. 2003. Distribución temporal del fitoplancton y epiliton en el 
río Piedra Blanca (Córdoba, Argentina). Limnetica 22: 19-34.

MCBRIDE S.A. \& EDGAR R.K. 1998. Janus cells unveiled: frustular morphometric variability in Gomphonema angustatum. Diatom Research 13: 293-310.

Nakov T., Ruck E.C., Galachyants Y., Spaulding S.A. \& THERIOT E.C. 2014. Molecular phylogeny of the Cymbellales (Bacillariophyceae, Heterokontophyta) with a comparison of models for accommodating rate variation across sites. Phycologia 53: 359-373.

PATRICK R. 1971. The effects of increasing light and temperature on the structure of diatom communities. Limnology and Oceanography 16: 405-421.

RiverA P. 1974. Diatomeas de agua dulce de Concepcion alrededores, Chile. Gayana Botánica 28: 3-134.

RiverA P. \& ARCos D. 1975. Diatomeas más comunes en la desembocadura del Rio Bio-Bio. Boletín de Sociedad de Biología de Concepción 49: 223-230.

Rivera P., PArra O., \& Gonzalez M. 1973. Fitoplancton del Estero Lenga, Chile. Gayana Botánica 23: 1-93.

Rivera P. \& VAldebenito H. 1979. Diatomeas recolectadas en las desembocaduras de los Rios Chivilingo, Laraquete y carampangue, Chile. Gayana Botánica 35: $1-99$.

Rumrich U., Lange-Bertalot H. \& Rumrich M. 2000. Diatomeen der Anden: von Venezuela bis Patagonien/Feuerland, und zwei weitere Beiträge. In: Iconographia
Diatolmologica (Ed. by H. LANGE-Bertalot), Vol. 9. A.R.G. Gantner Verlag K.G., Germany. 673 pp.

Santinelli N., Otano S. \& Pizzolon L. 1996. Phytoplankton periodicity and spatial distribution in Futaluafquen Lake, Patagonia Argentina. Verhandlungen Internationale Vereinigung Limnologie 26: 1772-1776.

Sastre A.V., Santinelli N., Bauer G.A., Ayestarán M.G. \& UYUA N.M. 2013. First record of the invasive diatom Didymosphenia geminata (Lyngbye). Schmidt in a Patagonian Andean river of Argentina. BioInvasions Records 2: 11-17.

Stoermer E.F., Kreis JR. R.G. \& Andresen N.A. 1999. Checklist of diatoms from the Laurentian Great Lakes. II. Journal of Great Lakes Research 25: 515-566.

TUJI A. 2005. Taxonomy of the Gomphoneis tetrastigmata species complex. Bulletin of the National Science Museum, Tokyo, Series B 31: 89-108.

Voilloud A.A. 2003. Cátalogo de diatomeas continentales y marinas de Argentina. Asociación Argentina de Ficología. $308 \mathrm{pp}$.

Wood E.J.F. 1961. Studies on Australian and New Zealand diatoms. V. The Rawson Collection of Recent diatoms. Transactions of the Royal Society of New Zealand 88: 699-712.

You Q., Kociolek J.P. \& Wang X. 2013. New Gomphoneis Cleve (Bacillariophyceae) species from Xinjiang Province, China. Phytotaxa 103: 1-24. 